Journal Universitas Muhammadiyah Gresik Engineering, Social Science, and Health International Conference (UMGESHIC)

UMGCINMATIC : $1^{\text {st }}$ Rethinking Education during Covid-19 Era: Challange and Innovation

\title{
THE DEVELOPMENT OF ENGLISH-SPEAKING SKILLS OF PRIMARY 3 STUDENTS IN COVID-19 SITUATION THROUGH FLIPPED CLASSROOM CONCEPT INTEGRATING WITH CLASSROOM ACTION RESEARCH
}

\author{
Author \\ Thawinee Ponsa ${ }^{1}$, Adinda Tasya ${ }^{2}$, Wanida Simpol ${ }^{3}$ \\ ${ }^{1}$ Ban Tungyai School, Phukradung, Loei 42180, Thailand \\ ${ }^{2}$ Universitas Muhammadiyah Gresik, East Java 61121, Indonesia \\ ${ }^{3}$ Loei Primary Educational Service Area Office 2, Wangsaphung, Loei 42130
}

\begin{abstract}
The English language has become a very crucial part of everyone's life. English communicative skill especially speaking skill is an important foundation for students to interact with others. Now that in the crisis of COVID-19 situation, face-to-face teaching is not available. As the result, the lack of speaking competency can lead to ineffective communication. The purposes of this study were (1.) to develop and verify the efficiency of the Flipped Classroom lesson plan for Primary 3 students (2.) to investigate the effectiveness of the Flipped Classroom lesson plan for Primary 3 students (3.) to study the result of student's English-speaking skill after learning by Flipped Classroom Concept and to examine students' satisfaction on flipped classroom teaching. A mixed research method was used, collecting data through various sources, including pre-and post-tests on speaking skills, a questionnaire ("Students' satisfaction on learning by Flipped Classroom Concept"), the teacher's in-class observations. The data were analyzed using descriptive statistics for data analysis including frequency, percentage, mean, standard deviation, average efficiency value, index of efficiency, and relative gain scores. The results of the research were as follows. 1) For the evaluation of the use of Flipped Classroom lesson plans for Primary 3 students, each of the lesson plans was averagely scored $4.44-4.50$. Overall, the lesson plans were averagely scored at a high level $(\overline{\mathrm{x}}=4.46, \mathrm{~S} . \mathrm{D} .=0.89)$, the efficiency $(\mathrm{E} 1 / \mathrm{E} 2)$ was 82.74/84.3 which was higher than the preset criteria. 2) The index of efficiency of Flipped Classroom lesson plans was 0.57692 , and the students' improvement increased 57.69 percent. 3) The students' English-speaking skills analyzed from the relative gain scores of English-speaking skill development results showed that the percentage of pretest scores was 62.9 and the percentage of posttest score was 84.3, and the percentage of growth score was 62.14 of which was interpreted as high level. The results show that not only did students' English-speaking skills were improved significantly but also the lesson was more engaging and active after the Flipped Classroom Concept was employed in their classroom. The findings of this study may benefit educators who are interested in applying technology in teaching English-speaking skills.
\end{abstract}

Keywords: English-speaking skill, Flipped Classroom, COVID-19 


\section{INTRODUCTION}

An English language is a communication tool that has been used all over the world. Especially in the current globalized where technology has been developed, information is now easier to be exchanged. Therefore, the ability to communicate in English becomes a foundation to be able to access the data and knowledge effectively. (Ministry of Education, 2008) The Basic Education Core Curriculum B.E.2521 (2008) Speaking is such a fundamental human behavior that we don't stop to analyze it unless there is something noticeable about it. For example, if a person is experiencing a speech pathology. (Bailey, 2004)

Under the spread of the COVID-19 pandemic, several schools including Ban Tungyai School are not able to practice face-to-face classes. The Ministry of Education suggested 4 ways to be applied; 1) On-site: students can come to school normally, 2) On-air: teaching broadcasted via DLTV, 3) Online: teachers' teaching through the teaching and learning materials provided and distributed from schools to the students, the teaching approach widely performed by the largest number of teachers, 4) On-demand: teaching format through various applications (Ministry of Education, 2021). Nonetheless, there are some concerns associated with the lack of devices such as mobile phones, laptops, or computers for Primary 3 students of Ban Tungyai School. On-demand seems to be the appropriate way to conduct the class since together with handouts and worksheets.

Ban Tungyai School is a small Primary school providing basic education level for kindergarten to Primary 6 with 9 staffs and 96 students in total. According to the 2020 Ordinary National Educational - Test (O-NET), the students had an English score of 28.44 on average which was considered lower than Thailand's standard. This indicated that students of Ban Tungyai school lacked English language skills. Specifically for Primary 3 students, insufficiency opportunity to practice English speaking skills which of the foundation to listening skills, reading skills, and also writing skills. In addition, students' attitudes toward learning the English language appeared negative as it seemed to be difficult and not a daily life matter. These issues along with the school's closing stemmed from students' English language acquisition.

Following the concerns mentioned above, the researcher, the English teacher of Primary 3 of Ban Tungyai School, recognized Communicative Language Teaching - CLT which is an approach emphasizing communication with others mainly using English (Celce-Murcia, 2014) and Flipped Classroom suitable for English teaching and learning for Primary 3 students of Ban Tungyai School.

\section{METHODS}

\subsection{Participants}

For this study, the participants were selected via the Purposive Sampling technique. The selected population consisted of 14 Primary 3 students of Ban Tungyai School, Phukradung District, Loei Province, Thailand in semester 1 of 2021 academic year.

\subsection{Measures}

Two research tools were used in this study:

1. Flipped Classroom lesson plans for Primary 3 students: 3 lesson plans, 10 hours, divided into 3 learning units as follows.

1. Unit: Unit: Personal Information Topic: Name, Age, School 3 hours

2. Unit: My School Topic: Inside the classroom 3 hours 
3. Unit: Family Topic: Family Member 4 hours

2. The questionnaire; "Students' satisfaction on learning by Flipped Classroom Concept"

\subsection{Procedure and design}

Procedure and design were one group pretest and posttest design. Learning units 1-3 were used to create a learning activity plans for data collection. The lesson plans were constructed through 6 stages as follows.

\section{Before teaching}

Stage 1: Plan. Teachers designed lesson plans by identifying teaching objectives, selecting teaching media and supplementary activities which are appropriate for the learner's ages, classrooms, and the school contexts.

Stage 2: Warm-up. Teachers record and prepare video for teaching. Teachers may record their own teaching or using other videos in which the content contained all learning indicators.

Stage 3: Share. Teachers share teaching videos to students and explain about the content of the video to be taught the classroom (at this stage, the teachers may create an activity or give out a preclass quiz for students to try before teaching in the classroom).

\section{In classroom}

Stage 4: Knowledge Sharing. This stage is an exchanging of knowledge to promote interaction in classroom. Teachers extend the students opportunity to discuss, exchange and ask questions based on the content they have already studied from the video to develop analytical thinking and communicating skill.

Stage 5: Group work. Students are divided into groups to achieve the results as planned. Dividing students into groups, students can work together on the topic assigned by the teachers or help each other choose a topic to work on to develop creative and collaborative skills (in the meantime, teachers can observe to assess students during presentations. Teachers may assign to do exercises or worksheets.)

Stage 6: Discussion. Students return in group again for group work presentation. It is a platform provided for all classmates to share opinions and ask questions.

\section{After teaching}

Review teaching to find out whether the designed lesson plans, videos, and materials included in the plans are effective or not, how effective the lesson plans are, and how are the results of the assessment and the evaluation of teachers' teaching as well.

Review the lesson plans after using for teaching, including teaching media and learning activities to find out how much the students understand the lessons.

Revise the lesson plans in case there are number of students remain questioned about the content. Teachers need to revise the lesson plans in order to enhance the students' better understanding.

Repeat if the teaching outcome is effective. Teachers repeat using the effective lesson plans and provide students with challenging activities so that students can use their advance level skills. 


\subsection{Data analysis}

(1.) Part 1: The evaluation results of the efficiency of the Flipped Classroom lesson plans for Primary 3 students

(2.) Part 2: The results of the review of the effectiveness of the Flipped Classroom lesson plan for Primary 3 students

(3.) Part3: The result of student's English-speaking skill after learning by Flipped Classroom Concept and students' satisfaction on flipped classroom teaching.

According to the study of the problem conditions and the database to develop students' English-speaking skills together with the flipped classroom concept, the researcher found that Ban Tungyai School context, students still have problems concerning listening, reading, writing, and especially speaking skills needed to be improved. The researcher studied how to apply the concept of Flipped Classroom to implement and assist students to successfully achieve learning objectives. Finally, the researcher has designed the lesson plans consisted of 3 plans for 10 hours, divided into 3 learning units as follows (Semester 1/2021).

1. Unit: Unit: Personal Information Topic: Name, Age, School

2. Unit: My School Topic: Inside the classroom

3. Unit: Family Topic: Family Member
3 hours

3 hours

4 hours

\section{RESULTS}

\section{Data analysis results}

The data was analyzed using descriptive statistics for data analysis including frequency, percentage, mean, standard deviation, average efficiency value, index of efficiency, and relative gain scores.

Part 1: The evaluation results of the efficiency of the Flipped Classroom lesson plans for Primary 3 students.

Table 1. The evaluation results of the efficiency of the Flipped Classroom lesson plans for Primary 3 students by 3 experts.

\begin{tabular}{|c|c|c|c|}
\hline $\begin{array}{c}\text { Lesson } \\
\text { Plans }\end{array}$ & Mean $(\overline{\boldsymbol{x}})$ & $\begin{array}{c}\text { Standard } \\
\text { Deviation (S.D) }\end{array}$ & Meaning \\
\hline 1 & 4.50 & 0.69 & Highest quality and quite high appropriateness \\
\hline 2 & 4.44 & 1.0 & High quality and high appropriateness \\
\hline 3 & 4.44 & 1.0 & High quality and high appropriateness \\
\hline Overall & $\mathbf{4 . 4 6}$ & $\mathbf{0 . 8 9}$ & High quality and high appropriateness \\
\hline
\end{tabular}


According to Table 1, the results of using Flipped Classroom lesson plans for Primary 3 students evaluated by experts were averagely scored from $4.44-4.50$, the overall mean score was 4.46 , and standard deviation was 0.89. For the efficiency of the Flipped Classroom lesson plans for Primary 3 students, it was found that the quality and appropriateness of each lesson plan was scored from the high to the highest level, and the overall assessment results of all lesson plans was at the high level $(\overline{\mathrm{x}}=4.46$, $\mathrm{SD}=0.89)$.

Part 2: The results of the review of the effectiveness of the Flipped Classroom lesson plan for Primary 3 students. The researcher examined the effectiveness of the lesson plans calculated from the scores of assessment of students' learning behaviours in class, assessment of worksheets, and pre-test and post-test scores. The results were presented in the following table.

Table 2. The effectiveness of the Flipped Classroom lesson plans for Primary 3 students.

\begin{tabular}{|c|c|c|c|}
\hline Activities/Scores & Full score & $\begin{array}{c}\text { Average } \\
\text { score }\end{array}$ & Percentage \\
\hline Activity 1 & 5 & 4.14 & 82.80 \\
\hline Activity 2 & 5 & 4.36 & 87.2 \\
\hline Activity 3 & 10 & 6.36 & 63.6 \\
\hline Activity 4 & 5 & 4.21 & 84.2 \\
\hline Activity 5 & 5 & 4.57 & 91.4 \\
\hline Activity 6 & 10 & 8.29 & 82.9 \\
\hline Activity 7 & 5 & 4.43 & 88.6 \\
\hline Activity 8 & 5 & 4.64 & 92.8 \\
\hline Activity 9 & 10 & 8.64 & 86.4 \\
\hline \multicolumn{2}{|c|}{ Average score } & 49.64 & \\
\hline \multicolumn{3}{|c|}{ E1 } & 82.74 \\
\hline After learning & 10 & 8.43 & 84.3 \\
\hline \multicolumn{3}{|c|}{ E2 } & 84.3 \\
\hline
\end{tabular}

From Table 2, the evaluation results showed the efficiency processes of the Flipped lesson plans for Primary 3 students was (E1) of 82.74 and the effectiveness of the lesson plans (E2) was 84.3. Consequently, the efficiency of the lesson plans development (E1/E2) was 82.74/84.3 which is higher than the pre-set criteria of $75 / 75$.

Table 3. Effectiveness Index of Flipped Classroom lesson plans for Primary 3 Students $(\mathrm{N}=14)$

\begin{tabular}{|c|c|c|}
\hline Total score of pre-test (10) & Total score of post-test (10) & ffectiveness Index (E.I.) \\
\hline 88 & 118 & 0.57692 \\
\hline
\end{tabular}

From Table 3, it was found that the effectiveness index of the flipped classroom lesson plans for Primary 3 students $(\mathrm{N}=14)$, as overall, was averagely 0.57692 . It is indicated that the Flipped Classroom 
lesson plans designed by the researcher increased the student achievement by $57.69 \%$. The efficiency (E1/E2) was 82.74/84.3 which was higher than the pre-set criteria.

Part3: The result of student's English-speaking skill after learning by Flipped Classroom Concept

\subsection{The Growth scores of students' English learning achievement}

The growth score of English-speaking skills of Primary 3 students analyzed by using relative ability growth scores according to the formula of Sirichai Kanchanawasi (2009), the criteria for assessment of the ability growth scores was as follows:

$\begin{array}{cl}\text { Growth score (percentage) } & \text { Meaning } \\ 76-100 & \text { Very high development } \\ 51-75 & \text { High development } \\ 26-50 & \text { Fair development } \\ 1-25 & \text { Less development } \\ \text { Lower than } 0 & \text { No development }\end{array}$

The results of the analysis the development of English-speaking skills of Primary 3 students was shown in the following table.

Table 4. Presented the relative growth scores of the development of English-speaking skill

\begin{tabular}{|c|c|c|c|c|}
\hline Student & $\begin{array}{c}\text { Before } \\
\text { learning }\end{array}$ & After learning & $\begin{array}{c}\text { Percentage of } \\
\text { development }\end{array}$ & $\begin{array}{c}\text { Level of } \\
\text { development }\end{array}$ \\
\hline 1 & 7 & 9 & 66.67 & Hight \\
\hline 2 & 6 & 9 & 75 & Hight \\
\hline 3 & 5 & 7 & 40 & Fair \\
\hline 4 & 7 & 10 & 100 & Very High \\
\hline 5 & 5 & 7 & 40 & Fair \\
\hline 6 & 7 & 10 & 100 & Very High \\
\hline 7 & 8 & 9 & 50 & High \\
\hline 8 & 7 & 9 & 66.67 & High \\
\hline 9 & 7 & 9 & 66.67 & High \\
\hline 10 & 6 & 8 & 50 & High \\
\hline 11 & 7 & 10 & 100 & Very High \\
\hline 12 & 5 & 6 & 20 & Low \\
\hline 13 & 5 & 6 & 20 & Low \\
\hline 14 & 6 & 9 & 75 & High \\
\hline Average & $\mathbf{6 . 2 9}$ & $\mathbf{8 . 4 3}$ & $\mathbf{6 2 . 1 4}$ & High \\
\hline Percentage & $\mathbf{6 2 . 9}$ & $\mathbf{8 4 . 3}$ & & \\
\hline
\end{tabular}

Primary 3 students who studied by using a flipped classroom lesson plans in the situation of COVID-19. It was found that the percentage of scores before learning was 62.9 , the percentage of score 
after learning by using the designed lesson plans was 84.3 , and the percentage students' growth scores was 62.14. Consequently, the overall development level of the students was considered at the high level.

Table 5. The development of English-speaking skill of Primary 3 students who studied by using a flipped classroom lesson plans in the situation of COVID-19.

\begin{tabular}{|c|c|c|c|c|c|}
\hline \multicolumn{4}{|c|}{ Number of students classified by the level of development } & \multirow{2}{*}{ Total } \\
\cline { 1 - 5 } Very high & high & Fair & Low & $\begin{array}{c}\text { No } \\
\text { development }\end{array}$ & \\
\hline 4 & 7 & 2 & 2 & - & 14 \\
\hline
\end{tabular}

According to the growth score shown in Table 6 regarding the academic achievement of Primary 3 students who studied using a flipped classroom lesson plans in the COVID-19 situation, there were 4 students had a very high improvement, 7 students with high level of development, and 2 students with fair level of development, and 2 students with low level of development.

Table 6. Students' satisfaction on flipped classroom teaching ( $\mathrm{N}=14)$

\begin{tabular}{|c|c|c|c|}
\hline Topic & Average & $\begin{array}{l}\text { Standard } \\
\text { Deviation } \\
\text { (S.D.) }\end{array}$ & $\begin{array}{l}\text { Satisfaction } \\
\text { Level }\end{array}$ \\
\hline 1. Lessons were design suiting students' needs & 4.5 & 0.52 & Highest \\
\hline $\begin{array}{l}\text { 2. Style, size and color of the text were clear and } \\
\text { appropriate. }\end{array}$ & 4.43 & 0.65 & Highest \\
\hline $\begin{array}{l}\text { 3. The contents were easy to understand, brief, and } \\
\text { provided connection between new and previous } \\
\text { knowledge. }\end{array}$ & 4.57 & 0.51 & Highest \\
\hline $\begin{array}{l}\text { 4. Contents were in accordance with the objectives of } \\
\text { the lessons. }\end{array}$ & 4.64 & 0.50 & Highest \\
\hline $\begin{array}{l}\text { 5. Teachers always facilitated students throughout } \\
\text { the lessons. }\end{array}$ & 4.71 & 0.47 & Highest \\
\hline $\begin{array}{l}\text { 6. The video was creative, interesting and easy to } \\
\text { understand }\end{array}$ & 4.21 & 0.58 & Highest \\
\hline 7. The audio was clear and precise. & 4.64 & 0.50 & Highest \\
\hline $\begin{array}{l}\text { 8. Students were able to develop their speaking skills } \\
\text { with the materials created. }\end{array}$ & 4.07 & 0.61 & Highest \\
\hline $\begin{array}{l}\text { 9. The lessons were flexible in accordance with } \\
\text { individual differences. }\end{array}$ & 4.71 & 0.47 & Highest \\
\hline $\begin{array}{l}\text { 10. The contents and materials encouraged students } \\
\text { to learn. }\end{array}$ & 4.71 & 0.47 & Highest \\
\hline Total & 45.19 & 5.28 & Highest \\
\hline Average & 4.519 & 0.53 & Highest \\
\hline
\end{tabular}




\section{UMGCINMATIC : $1^{\text {st }}$ Rethinking Education during Covid-19 Era: Challange and Innovation}

Volume 1 No 2

From Table 6 Students' satisfaction after using Flipped Classroom lesson plans was highly satisfied $\overline{(\boldsymbol{x}}=4.519$ and S.D. $=0.53)$

\section{DISCUSSION}

The results of using Flipped Classroom lesson plans for Primary 3 students evaluated by experts were averagely scored from $4.44-4.50$, the overall mean score was 4.46, and the standard deviation was 0.89. For the efficiency of the Flipped Classroom lesson plans for Primary 3 students, it was found that the quality and appropriateness of each lesson plan was scored from the high to the highest level, and the overall assessment results of all lesson plans were at the high level $(\overline{\mathrm{x}}=4.46, \mathrm{SD}=0.89)$.

The evaluation results showed the efficiency processes of the Flipped lesson plans for Primary 3 students was (E1) of 82.74 and the effectiveness of the lesson plans (E2) was 84.3. Consequently, the efficiency of the lesson plans development (E1/E2) was 82.74/84.3 which is higher than the preset criteria of $75 / 75$. It is possible that because the researcher had studied the concept of the flipped classroom concept together with Communicative Language Teaching (CLT) and designed the learning activities based on the 6-stage process by applying the concept of the flipped classroom that provide students chances to learn through peer collaboration. Moreover, students are now in control of the pace of the lessons and are more engaged with the learning activities which is consistent with (Jun Scott Chen Hsieh, 2016).

The results of the study of the effective index of the Flipped Classroom lesson plans for Primary 3 students $(\mathrm{N}=14)$ indicated that the overall average effectiveness index was 0.57692 . This means that the Flipped Classroom lesson plans improved the students' learning achievement 57.69 percent higher.

The evaluation results showed the efficiency processes of the Flipped lesson plans for Primary 3 students was (E1) of 82.74 and the effectiveness of the lesson plans (E2) was 84.3. Consequently, the efficiency of the lesson plans development (E1/E2) was 82.74/84.3. The academic achievement of Primary 3 students who studied using flipped classroom lesson plans in the COVID-19 situation, there were 4 students had a very high improvement, 7 students with the high level of development, and 2 students with the fair level of development, and 2 students with the low level of development. In addition, Students' satisfaction after using Flipped Classroom lesson plans was highly satisfied $((\overline{\boldsymbol{x}})=4.519$ and S.D. $=0.53)$.

\section{CONCLUSION}

The results of this research revealed that by applying the concept of the flipped classroom to develop the English-speaking skills of Primary 3 students, the lessons were flexible favored the student learning individually and collaboration among peers. The lessons appeared to be adjustable which increased teachers and students' rapports and decrease student anxiety since they can re-learn the lessons (Panich, 2013). This research is suitable for educators who are interested in applying technology in teaching English-speaking skills under the situation of Covid-19. The limitation of this research is the lack of devices for each student.

\section{ACKNOWLEDGEMENTS}

To be successfully complete, this research was funded by the project of the Research Grant for New Scholars. I do appreciate and would like to extend deeply thanks to Loei Primary Educational Service Area Office 2. Thank you Dr. Wanida Simpol, the research advisor and Dr. Nanthana 
Sarakitjanont for giving me suggestions, ideas, as well as guiding me to get through obstacles and difficulties in conducting research.

\section{REFERENCES}

Aksorn Charoentas Co., Ltd. (2021, October 01). Create a thinker in flipped classroom. Retrieved from

Alphabet Education: https://www.aksorn.com/flipped-classroom-1-Learning.

Bailey, K. (2004). Practical English Language Teaching: Speaking. New York: McGrawHill.

Botmas, W. (2019). Application on Learning English Vocabulary for Thai University Students in EFL Context. Thesis: Suranariee University.

Carl Reidsema, L. K. (2017). The Flipped Classroom Practice and Practices in Higher Education. Singapore: Springer Nature.

Celce-Murcia, M. (2014). Teaching English as a Second Language. Boston: National Geographic Learning.

Crystal, D. (2003). English as Global Language. New York: Cambridge University Press. Flipped Classroom. Journal of Nutrition Education and Behavior, 109-114.

Gilboy, M. B., Scott, H., \& Pazzaglia, G. (2015). Enhancing Student Engagement Using the Flipped Classroom. Journal of Nutrition Education and Behavior, 109-114.

Jarnok, A. (2018). Effectiveness of the instructor-designed instructional. Thesis: Suranaree University. Jun Scott Chen Hsieh, W.-C. V. (2016, February). Using the flipped classroom to enhance EFL Learning.

Ministry of Education. Basic Education Core Curriculum (2008). Bangkok: Agricultural Cooperative Association of Thailand Printing House, 2008.

Ministry of Education. Guidline for Schools under the COVID-19 situation. Bangkok: Agricultural Cooperative Association of Thailand Printing House, 2021.

Ministry of Education. Manual to design English Lessons to 3 levels of Internaional. Bangkok: Agricultural Cooperative Association of Thailand Printing House, 2019.

Nouri, J. (2016). The flipped classroom: for active, effective and increased learning - especially for low achievers. International Journal of Educational Technology in Higher Education, 33.

Panich, W.D. (2013). Teachers for Students: Flipped Classrooms.

Shuangjiang Li, J. S. (2017). Integration of Flipped Classroom Model for EFL.

Torstein Låg, R. G. ( 2019). Does the Flipped Classroom Improve Student Learning and Satisfaction? A Systematic Review and Meta-Analysis. AERA Open, 1-17.

T.Awidi, I., \& Paynter, M. (2019). The impact of a flipped classroom approach on student learning experience. Computers \& Education, 269-283.

Richard, J. C. (2010). Communicaty Language Teaching Today. New York: Cambridge University Press.

Roehling, P. E. (2018). Flipping the College Classroom. Singapore: Springer Nature.

Yang, R. C., \& Chen, Y. (2020). Implementing the flipped classroom approach in primary English classrooms in China. Education and Information Technologies, 1217-1235.

Zachary Walker, D. T. (2020). Flipped Classrooms with Diverse Leaners. Singapore: Springer Nature. 